\title{
The Impact of Pandemic COVID-19 on Tourism and Hospitality Education:
}

\author{
Case Study of Bali \\ Putu Indah Rahmawati*, Trianasari \\ Management Department \\ Universitas Pendidikan Ganesha \\ Bali, Indonesia \\ *indah.rahma@undiksha.ac.id, nanatrianasari01@undiksha.ac.id
}

\begin{abstract}
This research aims to investigate the impact of pandemic COVID-19 on tourism and hospitality education sector and then design some strategies on how to handle this situation. We choose Bali as the case study. Data were collected through semi-structured interviews with hotel managers, students, university lecturers and education policy makers. Data were analyzed using qualitative research approach. The result showed that the tourism and hotel education sector have been impacted by pandemic. Government forced the internship program to shorten into only 3 months and the next internship period is unpredictable. Students and lecturers agreed that the online teaching methods do not give the best learning experience for students. Therefore, several strategies were recommended on how Tourism and Hospitality Education better coordinated to handle this situation and to give a win-win solution for the tourism industry, students, and university.
\end{abstract}

Keywords-hotel, tourism, education, Covid-19 impact

\section{INTRODUCTION}

The world is threatened by the pandemic COVID-19 including Indonesia. The first COVID-19 case was first announced in Indonesia on March 2, 2020, and was reported in various mass media both print and online media. The pandemic is accelerating in Indonesia so that the government announced to restrict social activities. On March 17, 2020, the Indonesian government issued a Work From Home (WFH) policy which has led to significant changes in the economic sector.

The movement of people who want to school, work, official travel, and tourism has stopped. A significant decline in the use of transportation occurs in almost every mode of transportation, from air, land, water, and rail transportation. A substantial decline was then followed by the retail and tourism sectors. Travel for sightseeing is eliminated and tourist attractions are closed to an unspecified limit.

The COVID-19 pandemic has hit the tourism sector. Kompas media reported that Bali tourism loses up to $\mathrm{Rp} 9.7$ trillion per month when calculated from the average length of stay of tourists [1]. Hotels in Bali have laid off more than $90 \%$ of their employees because operations have stopped starting April 1, 2020 [2]. A situation like this has had a direct impact on the economy of the Balinese people who are almost $80 \%$ are dependent on the tourism industry. Tour guides, event organizers, and wedding photographers lost their jobs and switched professions just to survive. The discontinuation of hotel, restaurant, travel and tourism object operations has had a significant impact on student internship program in the tourism and hospitality sector.

Also, the COVID-19 pandemic has hit all education systems from preschool, elementary, middle school to college [3]. UNESCO estimates that nearly 900 million students have been affected by the closure of educational institutions due to the COVID-19 pandemic [4]. The Circular of the Minister of Education and Culture Number 4 of 2020 concerning the Implementation of Education Policies in a Coronavirus Disease 2019 Emergency (COVID-19) requires that the learning process be carried out through online learning [5].

The government policy to stop the pandemic has a huge impact on Indonesia's education system. Ministry of Education urges the whole education institutions in Indonesia to organize learning from home, which can be carried out in various forms of positive activities, such as project-based learning, humanitarian volunteers, or research that is relevant to efforts to stop the spread of the COVID-19 outbreak [5]. This paper provides an empirical narrative on the impact of the COVID-19 pandemic on vocational education, especially in the tourism sector in Indonesia. This study also examines alternative activities carried out by tourism education institutions to maintain the quality of learning and the quality of their graduates.

\section{METHODS}

This study was conducted in a qualitative research approach. A qualitative approach is a type of scientific research that involves gathering information from the research participants and actors to uncover meanings in and understanding of the issues being researched [6-8]. This paper 
will be useful for the global context, although the assessment was conducted in the context of Bali as a single case study. Data were gathered from multiple sources during the pandemic, from Mei to July 2020. Our paper focuses on the impact of COVID-19 on Tourism Vocational Education using Bali, Indonesia as a case study.

The primary data collected through in-depth interviews. The instruments used were interview guidelines. The in-depth interview technique was employed in this research because: (1) it enables the researcher to collect rich empirical data and dense explanations of the topic being studied [9]; (2) the nature of interview can ensure its validity and accuracy [10].

There were 5 hotel managers, 6 lecturers, and 10 students involved in this study. For confidentiality purposes, respondents were given the initials $\mathrm{R} 1, \mathrm{R} 2, \mathrm{R} 3, \mathrm{R} 4, \mathrm{R} 5$, and so on.

A purposive sampling technique was used to identify the key informants. In purposive sampling, respondents are not selected as a representative of a larger population but for their capacity to give rich information regarding the topic being researched. There is no limit to the number of respondents to make a purposive sample, as long as the desired information can be obtained and generated. In the case study, respondents were interviewed until data saturation was reached and no new information could be obtained $[8,11$,

Data obtained from in-depth interviews were analyzed by a qualitative method. The data gathered firstly needed to be transcribed and translated from a non-English language (Bahasa Indonesia) into English. The thematic approach was used to analyze the data. In the thematic analysis, once data is collected, it will be coded to search for similar themes and patterns and then to explore how the categorizations are presented by codes from case to case, from setting to setting. The rationale for choosing thematic analysis is that "a rigorous thematic approach can produce in-depth analyzes that answer specific research questions" [12]. After the data were rigorously analyzed, the researcher described the findings, according to the main themes. The following subsections present a detailed discussion of these themes mentioned by the respondents during in-depth interviews regarding the impact of Pandemic COVID -19 on vocational education on tourism in Bali, Indonesia.

\section{RESULTS AND DISCUSSION}

The tourism industry is a well-known leading industry sector in Bali. The importance of the tourism sector to communities makes this island vulnerable to the impact of pandemic COVID-19. Bali attracted more than 3.7 million international tourists and around 6.3 million domestic tourists in 2014 [13]. This figure rose significantly from 3.7 million international tourists in 2014 up to 6.2 million in 2019 [14] Detailed figures of international tourist arrivals in Bali can be seen in Table 1 .

However, international visitation suddenly stopped since government closed the international airport from April 2020. Bali has been relying on international visitation for several years. The largest international Tourist Generating Region (TGR) for Bali was Oceania, including Australia, China, Japan, Malaysia, and Singapore. Other significant international TGRs for Bali However, international visitation suddenly stops since the government closed the international airport from April 2020. Bali has been relying on international visitation for several years. The largest international Tourist Generating Region (TGR) for Bali was Oceania, including Australia, China, Japan, Malaysia, and Singapore. Other significant international TGRs for Bali were France and England (Statistic of Bali Province, 2019).

TABLE I. INTERNATIONAL VISITATION ON BALI

\begin{tabular}{|l|l|l|l|l|l|l|}
\hline Month & \multicolumn{1}{|c|}{$\mathbf{2 0 1 4}$} & \multicolumn{1}{|c|}{$\mathbf{2 0 1 5}$} & $\mathbf{2 0 1 6}$ & $\mathbf{2 0 1 7}$ & $\mathbf{2 0 1 8}$ & $\mathbf{2 0 1 9}$ \\
\hline Jan & 279.257 & 301.748 & 350.592 & 460.824 & 358.065 & 455.570 \\
\hline Feb & 275.795 & 338.991 & 375.744 & 453.985 & 452.423 & 437.456 \\
\hline Mar & 276.573 & 305.272 & 364.113 & 425.499 & 492.678 & 449.569 \\
\hline Apr & 280.096 & 313.763 & 380.767 & 477.464 & 516.777 & 477.069 \\
\hline May & 286.033 & 295.973 & 394.557 & 489.376 & 528.512 & 486.602 \\
\hline Jun & 330.396 & 359.702 & 405.835 & 504.141 & 544.550 & 549.516 \\
\hline Jul & 361.066 & 382.683 & 484.231 & 592.046 & 624.366 & 604.323 \\
\hline Aug & 336.763 & 303.621 & 438.135 & 601.884 & 573.766 & 606.412 \\
\hline Sep & 354.762 & 389.060 & 445.716 & 550.520 & 555.903 & 590.398 \\
\hline Oct & 341.651 & 369.447 & 432.215 & 465.085 & 517.889 & 567.967 \\
\hline Nov & 296.876 & 270.935 & 413.232 & 361.006 & 406.725 & 497.925 \\
\hline Dec & 347.370 & 370.640 & 442.800 & 315.909 & 498.819 & 552.403 \\
\hline Total & 3.766 .638 & 4.001 .835 & 4.927 .937 & 5.697 .739 & 6.070 .473 & 6.275 .210 \\
\hline
\end{tabular}

Source: Statistic of Bali Province, 2019

Inevitably, Bali is suffering soon after the international airport closed due to pandemic COVID-19. Bali has lost more than 6 million international visitations. Without foreign tourists the prediction of economic impact of pandemic will affect the accommodation industry by $81 \%$ and the transport sector up to $98 \%$ ]. The number of employees at laid off reaches millions of people throughout Indonesia. The total population of Bali alone reaches 4 million people with $80 \%$ depending on the tourism sector.

So far, this chapter has focused on the impact of pandemic COVID-19 based on secondary data. This paper presents some of the findings of empirical research based on in-depth interviews. The result of this investigation shows that the tourism stakeholders in Bali have experienced economic crises. This was reflected in the respondents' experiences on the impact of pandemic COVID-19 on the Bali economy in Table 2. 
TABLE II. RESPONDENTS' EXPERIENCES DURING THE PANDEMIC COVID-19

\begin{tabular}{|c|c|c|}
\hline $\begin{array}{l}\text { Experienced } \\
\text { Phenomena }\end{array}$ & $\begin{array}{l}\text { Impact on the } \\
\text { community and the } \\
\text { tourism sector } \\
\end{array}$ & $\begin{array}{c}\text { Examples of respondents' } \\
\text { experiences }\end{array}$ \\
\hline $\begin{array}{l}\text { International } \\
\text { visitation has } \\
\text { stopped } \\
\text { since April } \\
2020\end{array}$ & $\begin{array}{l}\text { Tourism industries such } \\
\text { as hotels, travel agents, } \\
\text { transports, cargo, ground } \\
\text { handlings were forced to } \\
\text { do layoffs. }\end{array}$ & $\begin{array}{l}\text { "I cannot pay my school } \\
\text { fee. My father has work } \\
\text { termination as a chef. Now, } \\
\text { I have to do sell street food } \\
\text { to survive for my family } \\
\text { basic needs" (R8) } \\
\text { "My father is a driver. He } \\
\text { used to drive for tourists. He } \\
\text { has lost his income" (R7) }\end{array}$ \\
\hline $\begin{array}{l}\text { Local } \\
\text { tourists } \\
\text { decline } \\
\text { significantly }\end{array}$ & $\begin{array}{l}\text { Food sellers, souvenir } \\
\text { shops, coffee shops, } \\
\text { cafes experienced drastic } \\
\text { decline in their income. }\end{array}$ & $\begin{array}{l}\text { "Not many tourists visit this } \\
\text { area. My mother's shop } \\
\text { closed" (R9) }\end{array}$ \\
\hline $\begin{array}{l}\text { Farmers are } \\
\text { overstock }\end{array}$ & $\begin{array}{l}\text { Farmers cannot sell their } \\
\text { produce as they used to } \\
\text { supply for hotel and } \\
\text { restaurants }\end{array}$ & $\begin{array}{l}\text { "My father is a farmer. He } \\
\text { cannot sell product because } \\
\text { hotels and restaurants were } \\
\text { closed. We have an } \\
\text { oversupply. We gave it to } \\
\text { my neighbour for a very } \\
\text { low price. Some of the } \\
\text { stocks still food waste. } \\
\text { Then, we give our products } \\
\text { to goat farm" (R10) }\end{array}$ \\
\hline
\end{tabular}

These economic crises are predicted to become worse as the tourism sector has a multiplier effect on other sectors. This economic crisis will place the local people in vulnerable financial conditions because the poor will have no capacity to pay the food prices. Lack of preparedness to face the economic crises has put Balinese under high pressure to survive during this pandemic. Most of them rely on family help or government support.

As illustrated in Table 2 that lots of students faced financial difficulty because their parent's income depends on the tourism industry. A range of relevant policies to support students were identified through secondary data collection. The Indonesian government has released some policies to support students financially through scholarship and school fee reduction.

Vocational Education on Tourism as predicted has been heavily impacted by pandemic. Based on interviews with lecturers, there were some programs highly impacted by COVID-19. Firstly, the job training program was terminated soon after the government release a ministry circular letter. As one respondent from a state university in the north mentioned: "The internship program which was supposed to be six months for the period (December 2019 to July 2020) had to be stopped suddenly since April 2020, the impact of this sudden termination was felt by students financially because most of the students have paid the rent for accommodation until their internship period over (R1)". Similarly, another respondent reported that many students were forced to stay in Bali because they were late to go back to their home town. The student then lives in Bali with a limited budget just to survive until domestic flights are allowed by the government. Of course, it causes stress for students who experience this situation (R2)".
Secondly, the practicum was inevitably disturbed by this situation. One respondent from a state university in Bali reported that the class for Food Production, Bar, Patisserie, Barista, and other courses that need practicum were disturbed by COVID-19. Online learning cannot guarantee that the students' skill has improved. The students only have limited tools for practice at home. As mentioned by one respondent as follow: "students were practice at home with limited tools and equipment, thus, far from the hotel requirement and expectation." (R2).

Moreover, it is hard to evaluate students' progress when one lecturer stated: “it is difficult to control student's progress because the assessment system is carried out online, the progress of practicum and physical presentations cannot be scored optimally (R4)". Based on the curriculum for tourism education, practicum consists of $60 \%$ and $40 \%$ of theory. Overall, $60 \%$ of subjects were impacted by COVID 19. As a respondent mentioned in the interview that "still alive and survive from COVID-19 is actually good enough. In education, it is difficult for us to maintain the quality of our graduates. Independent practice at home has reduced the quality of student practice results. Then, internship program which was not implemented optimally has reduced the quality of graduates. We cannot put a high standard in this kind of situation (R1)."

Thirdly, the field project in the tourism destination management course was also impacted. Students were not allowed to go field trips to conduct their research on tourism destinations. As mentioned by one respondent from Bali Tourism Institute, as follow: "field trip was canceled this year due to pandemic COVID-19. We cannot finish the project as our plan. Therefore, students were asked to finish their proposals only. We may continue the research project next year (R4)". Similarly, the final project for MICE was also canceled as students were not allowed to make any program that will gather lots of people. As one of the students reported, "MICE project was canceled. As a result, we have to make an online meeting that invites national keynote speakers and invites students from all over Indonesia. It was a new experience for students" (R5). A virtual meeting can be an alternative for a conventional meeting. However, in terms of economic benefit for the tourism industry, the virtual meeting does not help at all. One hotel manager mentioned that: "virtual meeting cost nothing for the organizer and the participants but not good for the tourism industry. There is no need to book flights, hotels, and tours for participants. Thus, there is no income for the tourism sectors" (R9).

The fourth, overseas internship program was also impacted. As the global crisis is approaching and the tourism business all over the world is declining, the need for internship students is also drop. As mentioned by one lecturer from a private university in Bali, "In a normal situation, students will go to Japan and USA for an internship. Since the pandemic, the program to send internship students overseas has stopped temporarily. We cannot do anything as the international flight also stopped by the Indonesian government" (R5). As 
mentioned earlier, national and local internship program also stopped. Students were forced to stay at home with a final project without industrial experience.

Last but not least, the students who graduate this year were also heavily impacted by the pandemic COVID-19. There is no graduation ceremony and no job vacancies from the tourism industry. One respondent stated: “ I apply any kind of job as long as I got a salary. Luckily, I got a job as a customer service at the bank" (R11). Another respondent mentioned: "I cannot find a job. I may help my father work at the farm until the tourism sector back to normal" (R12). Thousands of graduates this year should face difficulty in finding a job in the tourism industry.

\section{A. Strategy to improve teaching and learning experience during Pandemic COVID - 19}

Some of the obstacles caused by the existence of the COVID-19 pandemic have been described above. However, some positive impacts were also felt. According to Firman [15], the online learning process provides freedom for students to plan and carry out their learning independently. Limited interaction with lecturers makes students more independent in managing study time, doing and collecting assignments, and looking for learning resources to sharpen their ability to understand the material being lectured. Similarly, research from Windhiyana [16] reveals empirical data that online learning provides opportunities for student and lecturer interaction to be more flexible because learning can be carried out in a more flexible place and time and with a wider range.

In facing the impact of the COVID-19 pandemic, several educational institutions and universities have formulated strategies to maintain the quality of learning in the tourism sector. The results of interviews with several lecturers in several universities used the following strategy:

1) Replace the internship program with "a project-based learning" model: As one respondent from a private university reported as follow:

We use project-based learning as a substitute for the internship program. Our students ask to form a working group and then they make creative products, such as donuts or ice cream, which will be sold in the market. They design the product, the media for promotion, and then sell the products they make. The results are reported as well as the statistics of the promotion on social media. The assessment criteria are product quality, sales quantity, and the number of responses on social media. The better the product and the more sales that student makes the better the result that the students can get. (R2).

However, some universities that use the strategy of "switch the internship period". Students who are supposed to do an an internship from July to December 2020 period were forced to change the period to the next semester. During the COVID-19 pandemic, lecturers gave courses that could be given online while internship program would be given after the COVID situation improved. As stated by a lecturer:
We really hope that Bali will be open soon for international tourists so that our students can get internship experience in hotels or restaurants. We believe that a internship certificate in the tourism industry will be very valuable for students to be able to apply for jobs in the future. So, we keep the internship program, only the schedule is changed (R1).

2) Practicum will be carried out face-to-face following strict health protocols: One of the lecturers said that: "Students get bored with online lectures. Not all subjects can be done online.

So that, for the September to December 2020, practice will be carried out in the laboratory by following strict health protocols (R1).

Another respondent from the tourism training institute also conveyed the same thing, "practicum will be carried out faceto-face so that the quality of learning can be maintained" (R3)

3) Inviting tourism practitioners to a sharing session: The number of hotels and restaurants that have been temporarily closed has caused many hotel managers and practitioners to have a lot of free time and want to share experiences with students. As stated by several respondents:

We have invited hotel practitioners to share their experiences in the tourism industry. Students were very excited and many took part in the online seminars. Students from outside universities also joined these online seminars (R3).

We have invited our alumni who have been successful in the tourism industry to share their success stories. Alumni were happy to be able to meet students online. Students also enthusiastically participated in the sharing session by asking lots of questions. The interaction between students and alumni was very constructive for improving the quality of graduates even though it is held in a situation of the COVID-19 pandemic (R4).

The activity of inviting hotel practitioners through online media keeps students excited to take classes (R1)

From the results of the interview, it can be concluded that the lecturers have a strong willingness to maintain the quality of learning experience, even with the pandemic situation. Lecturers create some online sharing session from hotels and alumni to motivate students to remain optimistic that the tourism industry can return to its glory as before pandemic.

\section{CONCLUSION}

The tourism sector has devastated by the COVID-19 pandemic. As a result, tourism vocational education is also heavily impacted by this situation. The implementation of several programs has been disrupted, among others: internship program, work abroad program, field studies for tourism research, and practical activities in campus laboratories. The education institutions are preparing several strategies, including project-based learning program, switch internship schedule, inviting hotel / tourism practitioners to motivate students to 
remain optimistic that they can pass this challenge. While this research was conducted as an empirical narrative specific to Bali, the results are likely to resonate with many other tourism destinations. Finally, it is recommended to conduct further research using other tourist destination for more comprehensive results.

\section{ACKNOWLEDGMENT}

This research would not be possible without the generous funding from the Ministry of Higher Education Indonesia and Post-graduate Program of Universitas Pendidikan Ganesha, Bali, Indonesia. We are also grateful for support from tourism stakeholders that involved as respondents in this research.

\section{REFERENCES}

[1] Rosidin, Dampak Pandemi Covid-19 Pariwisata Rugi 9,7 Triliyun Tiap Bulan. Kompas, 2020. [Online] Retrieved from: https://regional.kompas.com/read/2020/05/13/17591091/dampakpandemi-covid-19-pariwisata-bali-rugi-rp-97-triliun-tiap-bulan Accessed on 30 Juli 2020.

[2] R. Angga, Efek Corona ke Pariwisata, 90\% Hotel di Bali Rumahkan Karyawan, Detik, 2020. [Online] Retreived from: https://travel.detik.com/travel-news/d-4970747/efek-corona-kepariwisata-90-hotel-di-bali-rumahkan-karyawan.

[3] A. Purwanto, R. Pramono, M. Asbari, P.B. Santoso, L.M. Wijayanti, C.H. Choi, and R.S. Putri, "Studi Eksploratif Dampak Pandemi COVID19 Terhadap Proses Pembelajaran Online di Sekolah Dasar," EduPsyCouns: Journal of Education, Psychology and Counseling, vol. 2, no. 1 , pp. 1-12, 2020.
[4] UNDP, Social and Economic Impact of Covid-19 in the Asia-Pacific Region, 2020.

[5] R. Putri, "Students' perspective on Learning From Home in pandemic COVID-19 situation," Seminar Nasional Hardiknas, pp. 17-24, 2020

[6] L. Dwyer, A. Gill, and N. Seetaram, Handbook of research methods in tourism: Quantitative and qualitative approaches. North hampton: Edward Elgar Pub, 2012.

[7] E. Sirakaya-Turk, W. Hammitt, and J.J. Vaske, Research methods for leisure, recreation and tourism, Wallingford, Oxfordshire; Cambridge: CABI, 2012.

[8] G. Guest, E.E. Namey, and M.L. Mitchell, Collecting qualitative data: a field manual for applied research, Thousand Oaks: SAGE Publications, 2013.

[9] A.J. Veal and G.W. Ticehurst, Business research methods: A managerial approach, Sydney: Pearson/Addison Wesley, 2005.

[10] G. Jennings, Tourism research, Milton, Qld: John Wiley \& Sons, 2010.

[11] E. Sirakaya-Turk, Research methods for leisure, recreation and tourism, Cambridge, MA: CABI, 2011.

[12] J.L. Krysik and J. Finn, Research for Effective Social Work Practice Effective Social Work Practice, Newyork, London: Routledge, 2010..

[13] Badan Pusat Statistik [BPS] Provinsi Bali, Statistik Wisatawan Mancanegara ke Bali 2014, [Online] Retrieved from: https://bali.bps.go.id/webbeta/website/pdf_publikasi/Statistik\%20Wisata wan\%20Mancanegara\%20ke\%20Bali\%202014.pdf

[14] Statistik of Bali Province, Number of Foreign Visitor to Indonesia and Bali, 1969-2019, [Online] Retrieved from: https://bali.bps.go.id/statictable/2018/02/09/28/jumlah-wisatawan-asingke-bali-dan-indonesia-1969-2019.html access on 20 of July 2020.

[15] F. Firman and S. Rahayu, "Pembelajaran online di tengah pandemi covid-19," Indonesian Journal of Educational Science (IJES), vol. 2, np/ 2, pp. 81-89, 2020.

[16] E. Windhiyana, "Dampak Covid-19 Terhadap Kegiatan Pembelajaran Online Di Perguruan Tinggi Kristen Di Indonesia,” Perspektif Ilmu Pendidikan, vol. 34, no. 1, pp. 1-8, 2020. 